\title{
Water Management in the Private Domain: A Comparative Analysis of Urban Water Management Practice in Nigeria's Niger Delta

\author{
Iniubong E. Ansa
} \\ Imoh E. Ukpong
}

Doi:10.5901/ajis.2015.v4n3s1p196

\section{Abstract}

\begin{abstract}
The paper compares three contextually different urban areas in Nigeria's Niger Delta to understand how private involvement in the management of water has affected the spatial and socio-economic circumstances of the population. A wide range of methods including semi-structured interviews, observations and analysis of secondary records were used to collect data. The paper observed different forms of private water services including commercial/private borehole, sachet/bottled water services, mobile supplies etc. Their mode of operations and services were not significantly different between the three urban areas despite differences in institutional histories. Findings show there is pervasive impact of private engagement in the supplies and management of water services in Nigeria's Niger Delta. However such engagement is haphazard, uncoordinated, unclear and highly unregulated. We observed that while public supplies target high income residential areas, the low income areas have been taken over by commercial water vendors to further capital accumulation. Consequently the low income earners employ all forms of daily rationing practice of allocating water to minimize expenditure while indirectly maximizing potential for health and other socio-economic problems. The paper argues that the involvement of the private sector in the management of water resources in Nigeria is a neoliberal agenda translated to reflect the demands and pressures of some major international financial organizations including the World Bank and IMF, rather than practical concerns for the citizens' interest and needs.
\end{abstract}

Keywords: Water management, private sector, urban areas, Niger Delta, Nigeria.

\section{Introduction}

The problem of water is much more pronounced especially in Africa where a combination of resource limitation and growing demand as well as poor management have rendered access to water supply highly inadequate. It is claimed that in rural Africa, about 65 per cent of the population do not have access to adequate supply of water. The report further noted that in urban areas, 25 per cent do not have access to adequate water (UN-Water/Africa, 2003). In Nigeria, the situation is as serious as the general situation in Africa as there are marked disparities not only between the north and the south, such disparities also occur within regions. In the face of these realities, the international community has responded with a number of proposals, the most relevant of which are, firstly, the UN Millennium Development Goals (MDGs), aimed at halving the proportion of the world's population that have no sustainable access to safe drinking water and sanitation by 2015 and, secondly, the Africa Water Vision for 2025, aimed at equitable and sustainable use of water for socioeconomic development.

Due to the many dimension of problems posed by water resources, countries have been forced to make rational choices between competing domestic, industrial, agricultural and commercial uses, among others. In one of the responses to these issues, a new paradigm has evolved to place water within the mechanism of market allocation. This entails the consideration of water as an economic good that would be subject to the dictates of demand and supply as well as emphasis on demand-oriented management strategy. Consequently, since the early 1990s, private sector participation (PSP) in water supply has been introduced into a number of transition and developing countries (Braadbaart, 2001: 5; Nickson, 1996: 2). The advocates of private sector involvement, ranging from international financial institutions (IFIs), bilateral agencies, OECD countries' governments, transnational corporations (TNCs), professional associations and scholars, have argued that PSP will improve efficiency, enable the extension of water services, raise the necessary investment finance, and relieve governments from budget deficits. On the otherhand, oppositional arguments against private sector involvement in water management have always centered their positions on the inherent universal and human right imperatives of water, which cannot be guaranteed within the context of profit drive and market concerns (Budds and McGranahan 2003, Marvin and Laurie 1999, K' Akumu 2006, etc). To address the question of social equity, infrastructural investments and human rights concerns, these and many other scholars have made cases for strong public 
interest, investments and supplies of water services for the people.

In Nigeria, Decree No. 25 of October, 1988 constitute the organizing legal framework for privatization and commercialization in the water sector. The policy was a part of the wider Structural Adjustment Programme (SAP) put in place for the purpose of restructuring the national economy. In spite of the many reasons for privatization, some people still believe it will not serve the interest of a greater number of Nigerians.

The debate on whether private or public has not been conclusive as scholars seem to be more polarized on these issues. In Nigeria, this polarization has become glaringly manifest, and is largely due to a lack of knowledge and information on the nature, depth and forms of private sector involvement in the water sector as well as the impacts and challenges of such involvements. If one looks around our urban centres various forms of private water services and management are noticed with haphazard and seemingly undefined operation. The most noticeable ones are sachet water sales, mobile water services (in tankers), commercial and private borehole operators, among others. At government and water corporation/companies levels, water services are increasingly being considered for outsourcing in addition to many other forms of commercial practices including lease of water equipment; commercialization of water services; contracting out water services and many other forms of partnership between public and private agencies.

At these levels, the study is comparative and is aimed at understanding the social, spatial and economic challenges associated with these forms of public-private relationships in the water services sector as well as the level of institutional supports underpinning their activities.

\section{Study Areas and Methods}

\subsection{General Background}

The study is part of a doctoral thesis on 'private sector involvement in water management in the Niger Delta: analysis of performance and challenges.' Three urban centers with diverse developmental and institutional histories were compared in Nigeria's Niger Delta region. The areas include Uyo urban (Akwa Ibom state); Calabar urban (Cross River state) and Port Harcourt urban (Rivers State) (Fig 1). These states share almost similar broad ecological characteristics with some internal variations. They all share physical boundaries with the Atlantic Ocean in the south with changes in variation, soil, geology and groundwater resources as one moves northward. The climate is generally humid tropical with some local variations in the northern part of the three states depending on local relief changes. Annual rainfall varies between $4000 \mathrm{~mm}$ in the coastal areas and $2000 \mathrm{~mm}$ in the inland areas. For northern Cross River, annual rainfall could be as low as $1500 \mathrm{~mm}$ because of significant variation in local relief configuration (NDES 2000).

General socioeconomic activities revolve around fishing, agriculture, small scale businesses, public sector occupation and petroleum oil-based activities. In spite of the wealth accruing from the exploration of petroleum resources in these states, NDES (2000) reported several developmental challenges in the areas of poor roads and telecommunication network, unstable power supply, housing problem, low level of literacy and educational development, waste accumulation, poor water supplies and sanitation services, poor healthcare infrastructure, among several others. The exploration of oil in the region has led to many environmental problems through frequent spillage, acid rain, destruction of the ecosystem and other social and economic livelihood supports (Akpan and Akpabio 2003). These have led to massive poverty for the populace and often create avenues for militancy and restiveness.

Specifically on water supply, data from the federal office of statistics (NDES 2000) show that water in these areas come from unsafe supply facilities, including rivers, lakes or ponds, unprotected wells and boreholes. The statistics classify available sources of potable water for household consumption as: pipe-borne, untreated pipe, borehole, protected well, unprotected well, river/lake/pond, vendor trucks and other categories. Poor access to adequate drinking water has serious implications for the general health, environment, economic activity and sustainable livelihoods. The lack of potable water in the rural areas, as well as severe shortages of pipe-borne water in urban centers, necessitates new policies and sets of institutions normally devised in ensuring supplies, but how effective are such institutions in addressing the problems? This is the central focus of this study.

\subsection{The three Urban Centers}

Port Harcourt, Calabar and Uyo have been used as the main urban centers for this study. These urban areas have different socio-economic and institutional histories.

The growth of Port Harcourt, for instance, in population and areal extent has been very phenomenal. Its population 
has grown from 500 in 1915; 30, 200 in 1944; 180,000 in 1963; 231,000 in 1973 and about 911,731 (Izeogu, 1989). Currently, Port Harcourt has an estimated urban population of about 2.7 million (Agbor and Onukwu, 2011). Besides rapid population growth, Port Harcourt has seen very high incidence of physical expansion, mostly in the rural-urban fringe to the north and the waterfronts to the south. Based on the Rivers state government estimate, there are not less than 14 distinct and well-known water side squatter settlements with an estimated population of 30,000 (cited in Izeogu, 1989). Most of the rural and semi-rural settlements taken over by Port Harcourt include Elekohia, Rumuomasi, Rumuokoroshe, Rumueme, Rumuola, Oroworukwo, Oromerizimgbu and Orogbum. It fringes have extended to Iriebe, Rumuolumeni, Choba and Rumuokoro. According to Izeogu (1989), the city has grown from 15.54 square kilometres in 1914 to a metropolis covering an area of 360 square kilometres in 1980s. The growth and expansion of Port Harcourt urban is largely attributable to its position in the former eastern region of Nigeria, as the nation's second port and the region's foremost industrial and commercial city, its location in the oil-rich Niger Delta and its function as a State capital.

The rise of Calabar is closely linked with its status as an international sea port (shipping out goods such as palm oil) which was recognized as far back as the 16th century (lliffe, 1995). During the era of the Atlantic slave trade, Calabar became a major port in the transportation of African slaves (Spark, 2004). Calabar once served as the seat of government of the Niger Coast protectorate, southern protectorate and oil Rivers protectorate. By this Calabar is effectively seen as the first Nigerian capital city. As the capital of Cross River state, Calabar is divided into Calabar municipal and Calabar south local government areas. It has an area of $406 \mathrm{~km}^{2}$ and a population of 371,022 at the 2006 census (Ottong et al, 2010). The inhabitants are mainly from the Greater Calabar district-Calabar south, Calabar municipality, Akpabuyo, Bakassi, Biase, Odukpani and Akamkpa. As commonly used in Nigeria, the term 'Calabar people' could also refer to both the indigenes of Greater Calabar as well as the people of the original south eastern state of Nigeria which is at present the people of Akwa Ibom and Cross River states. As a state capital, Calabar is currently growing in its population at a rate of about $5 \%$ while basic infrastructural services are not able to cope with the expanding demographic reality.

Uyo, the capital of Akwa Ibom state, assumes it present status following the creation of Akwa Ibom state in 1987. Its transformation from a small commercial town into an administrative capital has not only led to the rapid growth of economic activities, there is tremendous expansion in the physical infrastructures over the years. The position of Akwa Ibom state as an oil producing state has equally played a role in attracting industrial expansion and corresponding state investments in public infrastructures as a result of tremendous petroleum oil resource revenues. These have combined to make the city of Uyo the main centre of economic activities attracting migrants from different areas of the country. Obot et al (2009) noted progressive increase in land use from $5.30 \mathrm{~km} 2$ in 1960 when the city was a district headquarters to $186.30 \mathrm{~km}^{2}$ in 2005 as a capital city. The authors equally observed a rising trend in population growth from 87,311 persons in 1987 to 518511 in 2006 while 2010 population for the city was estimated at about 1000,000 at a growth rate of $5 \%$.

The most important concerns of urban growth and expansion in the Niger Delta region have to do with the capacities of available public infrastructures to cope with the phenomenal increase. Indeed, the urban sector, with its concentration of informal sector activities, plays a growing role in the economy of the Niger Delta region. Trading (17.4 per cent), services (9.8 per cent) and miscellaneous activities (11.1 per cent) are the most important areas of employment, after agriculture, fishing and forestry (UN Human Development Reports, 2006). Many problems have been identified as characterizing the phenomenal expansion and growth of urbanization in the Niger Delta to include poor quality housing and residential environment, problem of waste disposal; air, land, noise and water pollution as well as inadequate public infrastructures. One aspect of such problems easily manifest in the area of urban public water services. The inability of public water agencies to cope with the rising water needs of the urban citizens has led to the emergence of different forms of private engagements in the provision of water services. This trend is common across the main urban areas in the Niger Delta prompting the interest to understand the nature and effectiveness of such engagements in meeting the needs of the urban population.

\section{Study Methods}

This study was comparative specifically focusing on the three urban centers of Uyo, Calabar and Port Harcourt. A combination of case study approach, in-depth interviews and analysis of secondary documents/grey literature was used to understand the broad and local issues associated with water privatization, as well as the extent to which identified issues/practices differ from one area to another. For interview purpose, a two-stage sampling procedure was adopted for each urban location: a total of 20 streets were initially randomly selected, with a further random selection of 10 
households from each of the 20 streets. We ended up with 200 households from each of the urban areas for in-depth interviews, summing up to a total 600 households for the three urban locations. The head of each household was interviewed in a semi-structured manner. We emphasized on a whole range of issues including but not limited to sources of water, access to public and private water services, quality of water supply services, preferences and rating of service performance, household expenditure on water, challenges associated with water access, regulatory practices, general perception etc. We equally visited the respective urban water corporations for some interviews and clarifications bordering on institutional issues, regulatory practices, services provision, relationship with the private water suppliers etc. we interviewed commercial water service providers/operators to clarify some issues as well as understand their ideas/opinions. General institutional arrangements underpinning water privatization in Nigeria were analyzed within the framework of institutional decomposition and analysis (Saleth and Dinar 2004). This enabled us to access the availability and efficiency of relevant policies, legislations, administrative arrangement, regulatory practices, organizational and interagency coordination practices, conflicts and conflict resolution mechanisms, among others.

Emerging results were subjected to descriptive analysis using tables, frequencies and general discussions.

\section{Results}

Across the urban areas in the Niger Delta the private sector have been visible in the areas of commercial and private boreholes, sachet/table water, mobile supply services and various other forms of partnership with the public agencies in forms of service, management, lease and concession contracts. Others include build-operate-transfer (BOT), joint venture and divestitures (Table 1).

Table 1. Private Sector Participation in Water Provision Services in the Niger Delta

\begin{tabular}{|l|c|c|c|c|c|c|}
\hline \multirow{2}{*}{} & \multicolumn{2}{|c|}{ AKS } & \multicolumn{2}{c|}{ CRS } & \multicolumn{2}{c|}{ RS } \\
\cline { 2 - 7 } & response & $\%$ & response & $\%$ & response & $\%$ \\
\hline Commercial Borehole & 94 & 47 & 108 & 54 & 138 & 69 \\
\hline Private Borehole & 78 & 39 & 46 & 23 & 32 & 16 \\
\hline Sachet/Bottled water & 20 & 10 & 36 & 18 & 28 & 14 \\
\hline Mobile supplies & 8 & 4 & 10 & 5 & 2 & 1 \\
\hline Others & 0 & 0 & 0 & 0 & 0 & 0 \\
\hline Total & 200 & 100 & 200 & 100 & 200 & 100 \\
\hline
\end{tabular}

By Table 1, service types tend to vary across the urban areas probably due to environmental circumstances, development history and the degree of public institutional commitments to water service delivery. For instance, commercial borehole services tend to be most prominent means of securing water in the Cross River state (69\%) than in Akwa Ibom (54\%) and Rivers (47\%) states. On the other hand, private ownership of borehole tends to be higher in Akwa Ibom state (39\%) than the Cross River (23\%) and Rivers (16\%) states. Although Calabar urban (Cross River state) had the initial advantage of being the Federal Capital Territory, the urban area still depend on commercial water services than Uyo urban (Akwa Ibom state) and Port Harcourt urban (Rivers state). Possible explanation to this may be due to differences in environmental contexts, the degree of public commitment to water services and institutional regulatory practices. Table 2 describes the respondent's perspectives bordering on access to public water supply within the context of dominant private service.

Table 2. Do you have access to Public Sources of Water Supply in Your Areas?

\begin{tabular}{|c|c|c|c|c|c|c|}
\hline & \multicolumn{2}{|c|}{ AKS } & \multicolumn{2}{c|}{ CRS } & \multicolumn{2}{c|}{ RS } \\
\cline { 2 - 7 } & response & $\%$ & response & $\%$ & response & $\%$ \\
\hline Yes & 19 & 9.5 & 67 & 33.5 & 74 & 37 \\
\hline No & 181 & 90.5 & 133 & 66.5 & 126 & 63 \\
\hline Total & 200 & 100 & 200 & 100 & 200 & 100 \\
\hline
\end{tabular}

While Table 2 may not seem to adequately support the hypothesis of significant impact of public commitment in water services provision across the areas, it has, at least given some useful insights into the state practices in the provision of water services. Over $90 \%$ of the respondents said they do not have access to public sources of water supplies above 
$66.5 \%$ for Cross River and 63\% for Rivers states. Taken together the main sources of water supply (commercial and private borehole), it is clear that Akwa Ibom has the highest number of $86 \%$ respondents, closely followed by Rivers state (85\%) while the Cross River has $73 \%$ respondents. It is possible to argue that long years of institutional and urban development partly account for whatever differences observed. The Cross River state may have had the benefits of initial infrastructural supports and established public water services over the other two states.

Apart from relatively poor public services, the degree of private involvement in water services in the study areas is enhanced by the relative differences in the general environmental circumstances of the three states. Relative static water levels vary across the three states with Akwa Ibom and Rivers states having relative advantages over Cross River state. This, possibly, has been the major factors for individual investments in private and commercial supplies. While the minimum cost of drilling a borehole could range between $\# 150,000$ (\$937.5) and 200,000 (\$1250) in Akwa Ibom and Rivers states, the cost could be relatively higher for Cross River state. More so, Akwa Ibom and Rivers states rank the highest and second highest petroleum oil producing states respectively in the Niger Delta over Cross River state which virtually remains very insignificant in terms of oil production. Oil revenues mean more money in government and private hands which tend to create incentives for private investment in water production and services. This probably may be responsible for more private involvement across the three domains.

In general, the private sector seems to dominate water production and services in the study areas. Over $68 \%$ of the respondents recommended the private sector in the whole of the study areas. Based on Table 3, over $80.5 \%$ of the respondents in Akwa Ibom state judged the private sector favourably over the public sector. For Rivers state, $64 \%$ of the respondents said the private sector performed better over the public sector while $61 \%$ of the respondents made similar judgments in Cross River state (Table 3)

Table 3. Evaluation of the Public and Private Sources of Water Supply

\begin{tabular}{|l|c|c|c|c|c|c|}
\hline & \multicolumn{2}{|c|}{ AKS } & \multicolumn{2}{c|}{ CRS } & \multicolumn{2}{c|}{ RS } \\
\cline { 2 - 7 } & Response & $\%$ & Response & $\%$ & Response & $\%$ \\
\hline The public sector performs better & 39 & 19.5 & 78 & 39 & 72 & 36 \\
\hline The private sector performs better & 161 & 80.5 & 122 & 61 & 128 & 64 \\
\hline Total & 200 & 100 & 200 & 100 & 200 & 100 \\
\hline
\end{tabular}

Numerous irregularities, high cost of initial participation, low and selective coverage and general poor services were used by the respondents in downgrading the public water services provision in the study areas. For instance a male respondent in Uyo (in his early 40s) gave insight into the problem as follows: '...now before you are linked into the public supply network you have to have an initial capital of not less than $\# 30,000$ (\$187.5)...for a person like me... with family members... who may not earn up to $\# 20,000$ (\$125) such amount is like asking me to steal...I can't save such money....even if you can afford it, the services are such that you still have to keep spending extra money to buy water from commercial operators because of irregularities in the public sector...it is better to spend daily to buy water from the commercial vendors...' Apart from the initial high cost of being linked into the public network, the respondents were not even assured of regular public supplies given the general complaints of irregular public water services by those who use it. More so, the notion of running public water services as social services imply that people are likely to see government water services as free which tends to work against cost recovery. Akpabio et al (2007) had identified the idea of seeing water from the spiritual perspectives as the most important reason sustaining the notion of free public water service which certainly works against cost-recovery practices in the public sector. This seems to be one of the reasons the public sector gets more inclined towards those who are willing and more capable of paying for water services.

In response to the wider neoliberal policies of the Nigerian state, public water services in the states of the Niger Delta have introduced diverse forms of commercial and market practices to cater for the interest of certain capable segment of water consumers. A number of outsourcing practices in the areas of metering and billing services, capital investments, revenue collection etc. were being experimented by all the states urban Water Company limited. We gathered that while the state retains asset ownership and contribute in financial investments the respective urban water companies do enter into funding agreements and partnerships with external organizations such as the ADB and World Bank etc. with guarantees from the state. As at the time of this report, these practices were ongoing practices which were a bit too early to assess the results.

One important aspect of interest was the level of institutional arrangements as support mechanism for private engagement in water services across the three urban areas. Table 4 highlighted the level of institutional framework for private practice in the water services sector in the Niger Delta. 
Table 4. Institutional Framework for Private Sector Involvement in Water Service Management across the Niger Delta

\begin{tabular}{|c|c|c|c|c|}
\hline Institutional standards & AkS & CRS & RS & Performance Differences \\
\hline $\begin{array}{l}\text { Water pricing and cost } \\
\text { recovery policies/ } \\
\text { practices. }\end{array}$ & $\begin{array}{l}\text {-heavy state subsidies on water services } \\
\text {-private operators engage in arbitrary } \\
\text { pricing. }\end{array}$ & Same condition. & Same condition. & $\begin{array}{l}\text { No significant difference (in spite of } \\
\text { state subsidies, water services are } \\
\text { not affordable to the larger population } \\
\text { across the study areas) }\end{array}$ \\
\hline $\begin{array}{l}\text { Water services to the } \\
\text { public. }\end{array}$ & $\begin{array}{l}\text { Highly demand responsive at public and } \\
\text { private levels. }\end{array}$ & Same condition. & Same condition. & $\begin{array}{l}\text { No significant difference (low income } \\
\text { earners are disadvantaged) }\end{array}$ \\
\hline $\begin{array}{l}\text { User involvement in } \\
\text { water services } \\
\text { decisions. }\end{array}$ & $\begin{array}{l}\text { Akwa Ibom water company Ltd once } \\
\text { organized a stakeholder meeting } \\
\text { involving urban water users in } 2008 \text {. }\end{array}$ & \begin{tabular}{|l|} 
No records of \\
stakeholder platform \\
and engagements.
\end{tabular} & \begin{tabular}{|l|} 
No records of \\
stakeholder platform \\
and engagements.
\end{tabular} & $\begin{array}{l}\text { Urban water companies mostly run } \\
\text { arbitrary services without user } \\
\text { participation. }\end{array}$ \\
\hline $\begin{array}{l}\text { Legal sharing of } \\
\text { responsibilities in water } \\
\text { management between } \\
\text { governments and } \\
\text { private sector. }\end{array}$ & $\begin{array}{l}\text {-Federal laws dominate water services } \\
\text { legislations. } \\
\text {-no clear role definition for the private } \\
\text { sector. } \\
\text {-some laws have indirect effect on } \\
\text { private exploitation of ground water, e.g., } \\
\text { Land use Act } 1978 . \\
\text {-No single state law on water services } \\
\text { and management responsibilities. }\end{array}$ & Same condition. & Same condition. & $\begin{array}{l}\text { No significant difference (there is no } \\
\text { single governing authority and explicit } \\
\text { rules for regulating private activities in } \\
\text { the water sector across the region. }\end{array}$ \\
\hline Water rights of citizens. & $\begin{array}{l}\text { Subsumed under the land use Act for } \\
\text { groundwater. }\end{array}$ & Same condition. & Same condition. & $\begin{array}{l}\text { No significant difference (as there is } \\
\text { no clear definition of right of access to } \\
\text { water resources, ground water } \\
\text { pumping race has become very } \\
\text { common. }\end{array}$ \\
\hline \begin{tabular}{l|} 
Accountability \\
mechanism for private \\
water users and service \\
providers.
\end{tabular} & $\begin{array}{l}\text {-No explicit legislation at both Federal } \\
\text { and State levels. }\end{array}$ & Same condition. & Same condition. & $\begin{array}{l}\text { No significant difference (this has } \\
\text { encouraged reckless exploitation of } \\
\text { groundwater resources). }\end{array}$ \\
\hline $\begin{array}{l}\text { Regulatory framework } \\
\text { for private engagement } \\
\text { in water resources } \\
\text { exploitation. }\end{array}$ & \begin{tabular}{|l|}
-Urban water company supervises \\
operation and draw up arbitrary \\
standards for private providers. \\
-environment agency gives standard on \\
water project development, e.g., \\
borehole drilling.
\end{tabular} & Same condition. & Same condition. & $\begin{array}{l}\text { No significant difference (regulations } \\
\text { are hardly enforced) }\end{array}$ \\
\hline $\begin{array}{l}\text { Enforcement } \\
\text { mechanisms on private } \\
\text { or commercial practice. }\end{array}$ & $\begin{array}{l}\text {-Standards on borehole location and } \\
\text { water quality are handled by urban water } \\
\text { companies and the respective state } \\
\text { ministries of Environment. } \\
\text { - No pricing and tariff regulatory agencies } \\
\text { and authorities. }\end{array}$ & Same condition. & Same condition. & $\begin{array}{l}\text { No significant difference } \\
\text { (enforcements on location of private } \\
\text { water projects and quality are not } \\
\text { regularly enforced. } \\
\text {-arbitrary pricing and tariff regimes } \\
\text { rule private water operation). }\end{array}$ \\
\hline $\begin{array}{l}\text { Organizational } \\
\text { arrangements }\end{array}$ & $\begin{array}{l}\text {-public water company Ltd operate } \\
\text { commercial services } \\
\text {-private individuals operate private and } \\
\text { commercial boreholes } \\
\text {-small scale private water firms involves } \\
\text { in sachet water sales } \\
\text {-regional and multilateral organizations } \\
\text { e.g., ADB, World Bank/IMF etc partner } \\
\text { with public water company for } \\
\text { conditional funding. }\end{array}$ & Same condition & Same condition & $\begin{array}{l}\text { No significant difference (regional and } \\
\text { multilateral funding agencies } \\
\text { encourage full scale material and } \\
\text { service privatization of urban water } \\
\text { across the region as incentive for } \\
\text { funding public water projects). }\end{array}$ \\
\hline Funding & $\begin{array}{l}\text {-self-funded private operators } \\
\text {-absence of pubic incentives for private } \\
\text { operators } \\
\text {-loan supports from multilateral } \\
\text { organizations to public water companies } \\
\text { are conditional on privatizing and } \\
\text { commercializing water services }\end{array}$ & Same condition & Same condition & $\begin{array}{l}\text { No significant difference (private } \\
\text { water operators receive no support } \\
\text { from public funding agencies). }\end{array}$ \\
\hline Coordination activities & $\begin{array}{l}\text { Individuals, firms and public water } \\
\text { service providers operate independently } \\
\text { of each other } \\
\text {-inter-agency and inter-governmental } \\
\text { coordination in setting standard and } \\
\text { enforcements are hardly practicable }\end{array}$ & Same condition & Same condition & No significant difference \\
\hline
\end{tabular}


The result shows that none of the sampled states has clear law or edict to set standard and regulate practices. At interview with officials of the respective states, general reference was made of legislative Bills in the making. Respective state water agencies work on arbitrary guidelines and irregular monitoring practices. Akwa lbom state water company limited (AKWCL), for instance, imposes a license fee of \#16000 (\$100) as yearly license fees for private borehole operators. While some private borehole owners claimed being aware of such fees, most respondents seemed not quite aware of such fees. This is an indication of weak monitoring practice.

It was also observed that although the water agencies in the three states are said to be privatized, actual funding attention, staffing, supervision and other logistical supports all come from their respective governments. Not even any document has been tendered to the effect that the water companies operate as independent private organizations despite media claims. As other government parastatals and agencies, the study observed that the water agencies are characterized by daily bureaucratic and management problems including corruption, inadequate funding attention, and absence of staff capacity, among many other problems. There is a general confusion as to the role and status of the respective water agencies in the three states. This confusion manifested clearly in the contradictory presentation fielded during interview with agency experts and management staff. While the state water agencies depend solely on the scanty national institutional framework, we observed that none of the national institutional framework actually reflected debates and realities of water privatization. Most of the experts and staff seemed not quite informed and clear on the true situation on this in their respective states. This was reflected in the contradictory and inconsistent responses to information from some officials in the three state water agencies. There was an observable general trend of weak and uncoordinated institutional arrangements across the study areas. Because there were no clear institutional guidelines and standards, issues bordering on service regulation, tariff, water quality monitoring, water resources development, among others remain very weakly regulated and enforced. Consequently, private sector activities in the water sector function in unregulated environments posing challenges to standard and service quality.

\section{Discussion and Concluding Remarks}

The involvement of the private sector in the management of water supply services in Nigeria demonstrates the pervasive influence of the neoliberal policies in Nigeria's critical sector namely, water resources management. International policy translation and subsequent domestication at the national and local levels depend, to a large extent, on the capacity of the national and local system to meaningfully process and adapt such policies for the overall benefit of the system (Akpabio 2012 cites Mukhtarov 2009). As the findings in this paper have shown, there is pervasive impact of private engagement in the supplies and management of water services in Nigeria's Niger Delta. However such engagement is haphazard, uncoordinated, unclear and highly unregulated. Across the study areas, private management of water records no significant difference. The sector records large patronage and customer base over the public sector, not because of a healthy competitive advantage but largely the last resort of the highest number of the population owing to established cases of inefficiency and highly poor services in the public services sector. High incidence of irregular services, selective and very low coverage of the public water supply services were observed as important incentives for private and commercial borehole ownerships, mobile water services, sachet water phenomenon and other forms of private infiltration into water services delivery.

As important in life existence and economic activities, water services across the Niger Delta have been increasingly commodified beginning from 1998 when the idea of privatizing water services started receiving policy attention. Depending on location, we observed that service charge ranged between \#5 and \#20 per 25 liters of water. While public supplies target high income residential areas especially individuals with the financial capability to attract public taps and mains to private residence, the low income areas have been taken over by commercial water vendors to further capital accumulation (see Smith, 1984). The resulting spatial inequalities in water access have always worked to the disadvantage of the low income earners who are involved in daily rationing practice of allocating water to minimize expenditure while indirectly maximizing potential for health and other socio-economic problems. The current situation in Nigeria's Niger Delta is not significantly different from the observation in the literature that water services in medium and low income countries tend to work against the interest of the poor. Within this argument, Blakely et al (2005) recorded experiences in low income countries whereby households earning less than US\$ 1 per day were almost nine times more likely to lack improved water and sanitation than those earning more than US\$ 2 per day (cited in Akpabio 2012).

Although the idea of privatizing public service agencies set the direction for private involvement in water services, practical translation of this idea in Nigeria's water management situation remain largely unclear. For instance the water corporations of the three states under focus were converted to private companies in line with the privatization policy, and 
as a measure of strengthening efficiency and quality services. In the present circumstance, we observed that all administrative, funding and staffing, among others are still in the domains of government bureaucracy and political control. Staff capacity remains very low, and all the staff interviewed were still within the mental frame of public bureaucratic orientation, completely ignorant of the clear status of their organizations. Although the water agencies have changed names to reflect what should be their new 'privatized entities', it was quite difficult to substantiate such privatized image with some legal, legislative and other forms of necessary documents. What seems as a little change is the massive participation of individuals in water services provision through private and commercial borehole operation. The Land use Act of 1978 (which indirectly ceded available land resources on individual owners) was identified as the only legal framework that empowers individual land owners to have access to available water resources within their land areas. But the Water Resources Act of 1993 and 2004 (which ceded Nigeria's water resources exclusively in the control of the federal government of Nigeria) presents a contradiction to the land use Act and which tends to encourage 'forum shopping.' Given unclear regulatory mechanisms and weak monitoring framework, private water appropriation and commercial water trading have dominated water services operation in the study areas.

The main challenge here is that the private sector involvement in water services is not thoroughly regulated. This gives room to all forms of water services outlets without measures to control quality or check exploitation. Although it is the duty of the state and public agencies to monitor and regulate the private water spaces, such duties are hardly enforced. Consumer consciousness is equally absent as consumers hardly ask questions of rights, responsibilities, service costs and qualities. Lack of such consciousness leaves room for impunity and poor quality of services across the region. Given the role water plays in the livelihoods and economies of societies, the involvement of the private sector in its management could generate ample opportunity for delivering on access and complementing the activities of the public agencies. However, such opportunities would not be practicable if necessary ground rules of regulations are not highlighted and rigorously pursued.

In conclusion, we argue that the involvement of the private sector in the management of water resources in Nigeria is a neoliberal agenda translated to reflect the demands and pressures of some major international financial organizations including the World Bank and IMF, rather than practical concerns for the citizens' interest and needs. As a measure to engender support for policy, public sector interest and investments in water services have gradually and deliberately been weakened thereby offering incentives for private interest. Given the reality and observations from the study areas, it would make more meaningful sense to understand and solve the water needs of the general populace before outright pursuit of the privatization agenda.

\section{References}

Akpabio, E. M. (2012). Water Supply and Sanitation Services Sector in Nigeria: The policy Trend and Practice Constraints. ZEF Working Paper Series 96. Zentrüm für Entwicklungsforschung, University of Bonn, Germany.

Akpabio, E. M., Watson, N. M., Ite, U. E. and Ukpong, I. E. (2007) Integrated water resources management in the Cross River Basin, Nigeria. International Journal of Water Resources Development 23:4: 691-708. London.

Akpan, N. S. and Akpabio, E. M. (2003) Youth restiveness and violence in the Niger Delta Region of Nigeria: Implications and suggested solutions. International Journal of Development Issues 2:2, 37-58. University of Queensland, Australia.

Agbor, E. and A. Onukwu (2011). The young professional's guide to Port Harcourt, Nigeria. Vol. 7, No. 1. http://www.spe.org/twa/print/ archives/2011/2011v7n1/14YPGuide.pdf

Ayoade, J. O. and B. L. Oyebande (1983): Water Resources. In J. S. Oguntoyinbo, O. O. Areola, M. Filani (eds). A Geography of Nigerian Development. Heinemann Educational Books (Nig.) Ltd.

Braadbaart, O. (2001) Privatizing Water. The Jakarta Concession and the Limits of Contract. Paper presented at KITLV Jubilee Workshop on "Water as a Life-Giving and a Deadly Force" (Leiden, the Netherlands, 14th-16th June 2001).

Budds, J. \& McGranahan, G. (2003). Are Debates on Water Privatization Missing the Points? Experiences from Africa, Asia and Latin America. Environment and Urbanization 15 (2): 87-113

Calder, I. R. (1999). The Blue Revolution. Landuse and Integrated Water Resources Management. Earthscan Publications Ltd, London

Heathcote, I. (1998). Integrated Watershed Management-Principles and Practices, John Wiley and Sons Inc. USA.

Iliffe, J. (1995). Africans: the history of a continent. Cambridge University Press. P.149.

Izeogu, C. V. (1989). Urban development and the environment in Port Harcourt. Environment and Urbanization 1: 59-68.

K' Akumu, O. A. (2006). Privatization Model for Water Enterprise in Kenya. Water Policy (8): 539-557.

Marvin, S. \& Laurie, N. (1999). An Emerging Logic of Urban Water Management, Cochabamba, Bolivia. Urban Studies 36 (2): 341-357.

Mukhtarov, F. (2009). The Hegemony of integrated water resources management: a study of policy translation in England, Turkey and Kazakhstan. Thesis submitted to the Department of Environmental and Policy of Central European University in Part fulfillment of the degree of doctor of philosophy. Budapest.

NDES (2000). Niger Delta Development Priorities and Action Plan. Phase II Report. Vol. 2. 
Nickson, A. (1996) Urban water supply sector review. Papers in the Role of Government in Adjusting Economies, No 7, International Development Department, University of Birmingham, for the Economic and Social Research Council of the British Government, January 1996.

Obot, J. U., E. E. Etim and J. Atser (2009). Intra-urban traffic and parking demand in Uyo urban area. Global Journal of Social Sciences $8(2): 61-68$

Ottong, J. G., S. O. Ering and F. U. Akpan (2010). The population situation in Cross River state of Nigeria and its implication for socioeconomic development. Observations from the 1991 and 2006 censuses. Journal of Emerging Trends in Educational Research and Policy studies 1 (1): 36-42.

Saleth, R. and A. Dinar (2004). The institutional economics of water: a cross-country analysis of institutions and performance. The World Bank. Edward Elgar, UK.

Smith, N. (1984). Uneven Development: Nature, Capital, and the Production of Space. Oxford: Blackwell.

Sparks, J. (2004). The two princes of Calabar: an Eighteenth-century Atlantic Odyssey. Havard University Press. P.39.

UNDP (2006). Niger Delta Human Development Report. United Nations Development Programme. Abuja.

UN-Water/Africa (2003). Africa Water Vision 2025: Equitable and Sustainable Use of Water for Socio economic Development.

World Bank (2003). Water Resources Sector Strategy: Strategic Directions for World Bank Engagement. World Bank, Washington DC. 